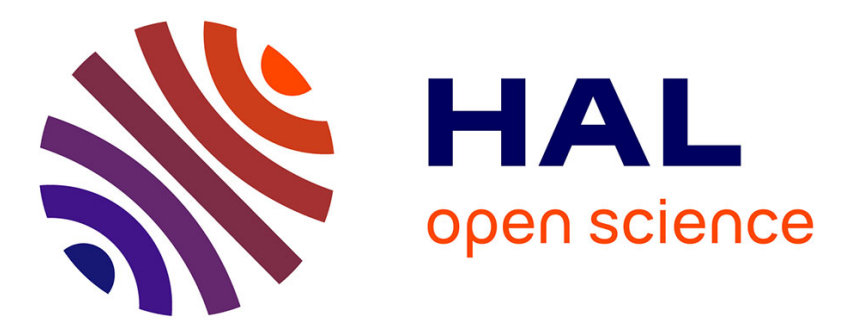

\title{
Atmospheric concentrations of carbon dioxide and its isotopic composition in southern Poland: comparison of high-altitude mountain site and a near-by urban environment
}

\author{
L. Chmura, K. Rozanski, J. M. Necki, M. Zimnoch, T. Kuc, A. Korus
}

\section{To cite this version:}

L. Chmura, K. Rozanski, J. M. Necki, M. Zimnoch, T. Kuc, et al.. Atmospheric concentrations of carbon dioxide and its isotopic composition in southern Poland: comparison of high-altitude mountain site and a near-by urban environment. Biogeosciences Discussions, 2005, 2 (6), pp.1849-1865. hal00297830

\section{HAL Id: hal-00297830 \\ https://hal.science/hal-00297830}

Submitted on 16 Dec 2005

HAL is a multi-disciplinary open access archive for the deposit and dissemination of scientific research documents, whether they are published or not. The documents may come from teaching and research institutions in France or abroad, or from public or private research centers.
L'archive ouverte pluridisciplinaire HAL, est destinée au dépôt et à la diffusion de documents scientifiques de niveau recherche, publiés ou non, émanant des établissements d'enseignement et de recherche français ou étrangers, des laboratoires publics ou privés. 
Carbon dioxide in

L. Chmura et al.

\section{Atmospheric concentrations of carbon dioxide and its isotopic composition in southern Poland: comparison of high-altitude mountain site and a near-by urban environment}

L. Chmura, K. Rozanski, J. M. Necki, M. Zimnoch, T. Kuc, and A. Korus

AGH University of Science and Technology, Krakow, Poland

Received: 30 September 2005 - Accepted: 28 October 2005 - Published: 16 December 2005 Correspondence to: J. M. Necki (necki@agh.edu.pl)

(c) 2005 Author(s). This work is licensed under a Creative Commons License.

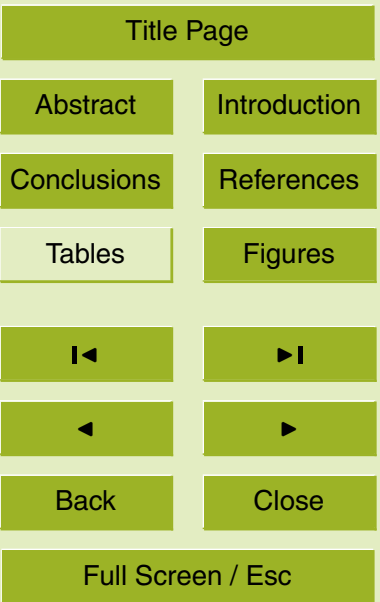

Print Version

Interactive Discussion 


\section{Abstract}

The results of regular observations of atmospheric $\mathrm{CO}_{2}$ mixing ratios and its carbon isotope composition $\left(\delta^{13} \mathrm{C}, \Delta^{14} \mathrm{C}\right)$, carried out at two continental sites located in central Europe are presented and discussed. The sites (Kasprowy Wierch, $49^{\circ} 14^{\prime} \mathrm{N}, 19^{\circ} 59^{\prime} \mathrm{E}$, $51989 \mathrm{~m}$ a.s.l.; Krakow, $50^{\circ} 04^{\prime} \mathrm{N}, 19^{\circ} 55^{\prime} \mathrm{E}, 220 \mathrm{~m}$ a.s.l.), are located in two contrasting environments: (i) high-altitude mountaneous area, relatively free of anthropogenic influences, and (ii) typical urban environment with numerous local sources of carbon dioxide. Despite of relative proximity of those sites (ca. $100 \mathrm{~km}$ ), substantial differences in both the recorded $\mathrm{CO}_{2}$ levels and their isotopic composition were detected. The $\mathrm{CO}_{2}$ 10 mixing ratios measured in the urban atmosphere revealed quasi-permanent excess concentration of this gas when compared with near-by background atmosphere. The annual mean $\mathrm{CO}_{2}$ concentration recorded in Krakow in 2004 was almost $10 \%$ higher than that recorded at high-altitude mountain site (Kasprowy Wierch). Such effect is occuring probably in all urban centers. Carbon isotopic composition of atmospheric $\mathrm{CO}_{2}$ proved to be efficient tool for identification the surface $\mathrm{CO}_{2}$ fluxes into the atmosphere related to fossil fuel burning and their influence on the recorded levels of this gas in the local atmosphere. The available records of $\Delta^{14} \mathrm{C}$ for Krakow and Kasprowy Wierch suggest gradual reduction of ${ }^{14} \mathrm{C}$-free $\mathrm{CO}_{2}$ fluxes into the urban atmosphere of Krakow in the past several years.

\section{Introduction}

Abrupt increase of atmospheric $\mathrm{CO}_{2}$ concentration over the last 100 years, by far exceeding the natural variations, has been unequivocally attributed to human activities (Keeling, 1993; GLOBALVIEW, 2004). The anthropogenic impact on the global carbon cycle is mainly related to fossil fuel and biomass burning, land-use changes, as well
BGD

2, 1849-1865, 2005

Carbon dioxide in southern Poland

L. Chmura et al.

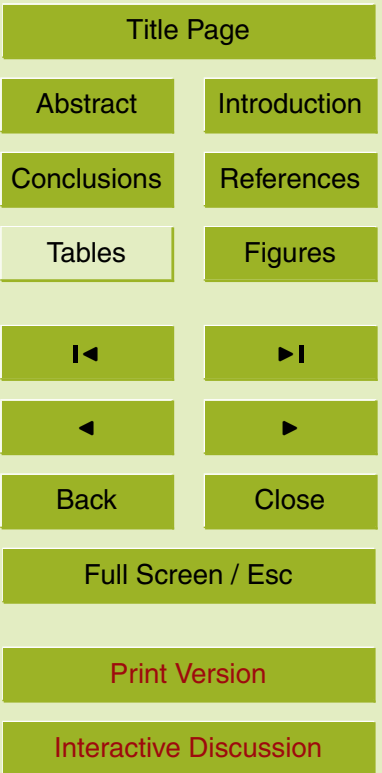

EGU 
magnitude of the $\mathrm{CO}_{2}$ fluxes entering and leaving the atmospheric carbon reservoir. These short-term changes have both anthropogenic and natural origin (Cias et al., 1995; Keeling et al., 1995). Identification and quantification of sources and sinks of carbon and their temporal and spatial variability on both global and regional scales, 5 is a prerequisite for a better understanding of the dynamics of carbon cycle and its response to ever increasing human impact (IPCC, 2001).

Development of reliable carbon cycle models requires adequate observational data. Up to now they are delivered mostly by the existing global and regional monitoring networks (GLOBALVIEW, 2004). Apart from the mixing ratios, also the isotopic com10 position of carbon dioxide is measured in number of locations. Isotope characteristics of carbon dioxide constitute a powerful tool for identification of sources and sinks of carbon and partitioning of carbon derived from burning of fossil fuels (Levin and Hesshaimer, 2000; Démeny and Haszpra, 2002; Kuc et al., 2003).

The transition to market economy in east European countries is associated with 15 major changes of industrial technologies and resulting shifts in the structure of total energy consumption (gradual shift from coal to oil and natural gas). These changes have significant impact on strength and distribution of major sources of greenhouse gas emissions, in particular $\mathrm{CO}_{2}$, into the atmosphere in this part of Europe. Large urban and industrial centres are exposed to these emissions and the extent of their changes over the past years need to be quantified.

This work presents data gathered in southern Poland, mostly during the time period 2000-2004. They illustrate the variability of atmospheric carbon dioxide, both with respect to its mixing ratios and isotopic composition, recorded at two ground-level continental sites located in contrasting environments: (i) high-altitude mountaneous area, relatively free of anthropogenic influences, and (ii) typical urban environment with numerous local sources of carbon dioxide. The distance between both sites is approximately $100 \mathrm{~km}$.

BGD

2, 1849-1865, 2005

Carbon dioxide in southern Poland

L. Chmura et al.

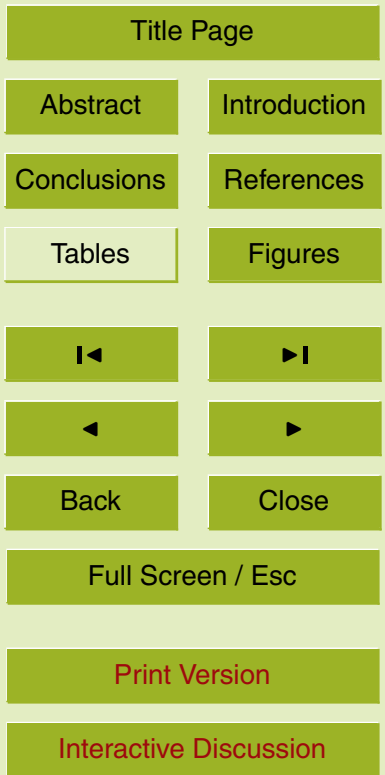

EGU 


\section{Site description}

\subsection{Kasprowy Wierch}

The Kasprowy Wierch station is located in the south of Poland, within the High Tatra Mountains (Fig. 1a). The meteorological observatory which houses the monitoring 5 station is located at the top of a mountain peak called Kasprowy Wierch $\left(49^{\circ} 14^{\prime} \mathrm{N}\right.$, $19^{\circ} 59^{\prime} \mathrm{E}, 1989 \mathrm{~m}$ a.s.I., $300 \mathrm{~m}$ above the tree line). Kasprowy Wierch is situated at the intersection of three main valleys, at the border between Poland and Slovak Republic. The nearest town, Zakopane, is located approximately $900 \mathrm{~m}$ below, $6 \mathrm{~km}$ north of Kasprowy Wierch. This is a small tourist town. During winter holiday period (January,

10 February), relatively large amounts of wood and fossil fuels are combusted in the valley. The Kasprowy Wierch observatory is equipped with electrical heating system and does not use any fossil fuel. During wintertime, diesel-operated snow cars are used in the near-by valleys to maintain proper conditions for skiing.

The climate of Kasprowy Wierch area is typical for a continental mountain location, with relatively large diurnal and seasonal variations of temperature, high precipitation rate, frequent changes of atmospheric pressure and strong winds. The winds are blowing predominantly along the N-S axis, with the average speed of around $7 \mathrm{~m} \mathrm{~s}^{-1}$. Winter season lasts typically for 8 months and ends up rapidly due to strong fohn circulation.

20 Regular observations of atmospheric $\mathrm{CO}_{2}$ concentrations started at Kasprowy Wierch in 1994, as a joint project of the AGH University of Science and Technology, Krakow, Poland, and the University of Heidelberg, Germany. Continuous measurements using GC technique were initiated in 1996. The intake of outside air is located ca. $1 \mathrm{~m}$ above the roof of the observatory and ca. $6 \mathrm{~m}$ above the local ground. The al. (2003).

Since Kasprowy Wierch is situated within the transition zone between free troposphere and the planetary boundary layer and is relatively free of local influences, this

BGD

2, 1849-1865, 2005

\section{Carbon dioxide in southern Poland}

L. Chmura et al.

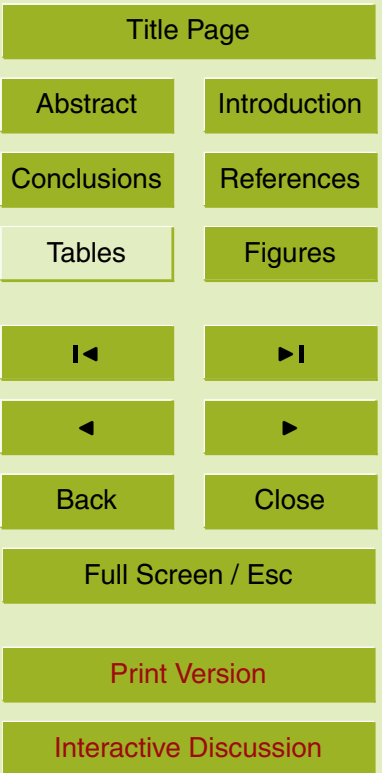

EGU 
site can be considered as a regional reference station for trace gas measurements in the lower atmosphere.

BGD

2, 1849-1865, 2005

\subsection{Krakow}

Krakow $\left(50^{\circ} 04^{\prime} \mathrm{N}, 19^{\circ} 55^{\prime} \mathrm{E}, 220 \mathrm{~m}\right.$ a.s.l.), the second largest city of Poland, is located 5 approximately $100 \mathrm{~km}$ north of Kasprowy Wierch. With more than 800 thousands inhabitants, rapidly growing car traffic and significant industrial activities, it represents a typical urban environment. Moreover, with the prevailing westerly circulation, the Krakow region is under substantial influence of a large coal mining and industrial centre (Upper Silesia) located approximately $60 \mathrm{~km}$ west of the city. Characteristic features of the local climate are generally weak winds (annual average around $2.7 \mathrm{~m} / \mathrm{s}$ ) and frequent inversions, extending sometimes over several days (particularly during winter time). These factors favour accumulation of surface gaseous emissions within the lower atmosphere above the city. The sampling site was situated on the University campus (Fig. 1b) located in the western part of the city, bordering recreation and sports grounds. The air intake was located on the roof of the Faculty building, approximately $20 \mathrm{~m}$ above the ground level.

\section{Analytical methods}

The GC technique was employed at both sites to measure the mixing ratios of atmospheric $\mathrm{CO}_{2}$. Automated gas chromatograph (Hewlett Packard, Series 5890 with FID detector and $\mathrm{Ni}$ catalyst for conversion of $\mathrm{CO}_{2}$ to $\mathrm{CH}_{4}$ and Porapak $\mathrm{Q}$ column) was used. Reference working standard was injected after each sample. Four determinations of $\mathrm{CO}_{2}$ mixing ratios per hour were performed in automatic mode of operation. The air was cryogenically dried at $-70^{\circ} \mathrm{C}$ prior to analysis. Typical reproducibility of the mixing ratio measurements was around $\pm 0.1 \mathrm{ppm}$. All $\mathrm{CO}_{2}$ data are reported in

\section{Carbon dioxide in southern Poland}

L. Chmura et al.

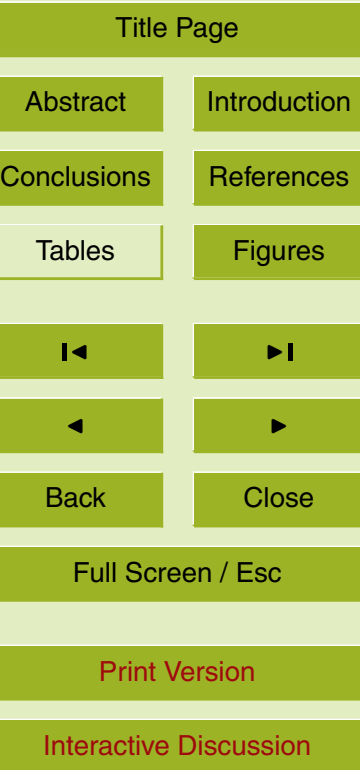

EGU 
calibrated against primary reference gases.

For isotope measurements the atmospheric $\mathrm{CO}_{2}$ was continuously sampled by sorption on molecular sieve, in bi-weekly intervals. After thermal desorption, the radiocarbon activity in the given $\mathrm{CO}_{2}$ sample was measured using benzene synthesis method 5 and liquid scintillation spectrometry (Florkowski et al., 1975). The ${ }^{13} \mathrm{C} /{ }^{12} \mathrm{C}$ ratio in the collected $\mathrm{CO}_{2}$ was determined by mass spectrometry.

Stable isotope composition of the analysed $\mathrm{CO}_{2}$ samples is expressed in $\delta$ notation defined as per mille deviation of the carbon isotope ratio measured in the sample $\left({ }^{13} \mathrm{C} /{ }^{12} \mathrm{C}\right)$ from that measured in the internationally accepted standard, VPDB (Coplen, 10 1996). The radiocarbon concentration of the measured samples was expressed as $\Delta^{14} \mathrm{C}=\left[\left(\mathrm{A}_{s} / \mathrm{A}_{s t}-1\right] \times 1000\right.$ where $\mathrm{A}_{s}$ and $\mathrm{A}_{s t}$ stand for specific activity of the sample and the standard, respectively. $A_{s t}$ is corrected for decay since 1950 and normalized to $\delta{ }^{13} \mathrm{C}=-19.0 \%$ o. $\mathrm{A}_{s}$ is normalized to $\delta^{13} \mathrm{C}=-25 \%$ (Stuiver and Pollach, 1977). Typical uncertainties of isotope analyses ( \pm 1 sigma) are in the order of $\pm 0.1 \%$ for $\delta^{13} \mathrm{C}$ and $58 \%$ ofor $\Delta^{14} \mathrm{C}$.

\section{Results and discussion}

The $\mathrm{CO}_{2}$ mixing ratios recorded at Kasprowy Wierch and Karkow stations are shown in Figs. $2 a$ and b, respectively. The record for Kasprowy Wierch starts in June 1996 while in Krakow the measurements started only in 2003. Sampling at Kasprowy Wierch site was quasi continuous (except of breaks caused by technical problems), in contrary to Krakow where it had a form of campaigns, whenever the GC instrument was available for this type of measurements.

It is apparent from Fig. 2 that these two records of $\mathrm{CO}_{2}$ mixing ratios differ considerably. The seasonal cycle, with reduced $\mathrm{CO}_{2}$ mixing ratios during summer months, is well pronounced at Kasprowy Wierch. The presented record reveals typical behaviour of atmospheric $\mathrm{CO}_{2}$ observed at mid-latitude continental sites of the Northern Hemisphere. The winter maximum ends in March, when the photosynthetic sink starts to 1854

\section{BGD}

$2,1849-1865,2005$

\section{Carbon dioxide in southern Poland}

L. Chmura et al.

\section{Title Page}

Abstract Introduction

Conclusions

Tables

References

Figures

14

4

Back

Full Screen / Esc

Print Version

Interactive Discussion

EGU 
operate. From that time on, the $\mathrm{CO}_{2}$ mixing ratio gradually decreases, reaching a minimum in August/September. Afterwards, the $\mathrm{CO}_{2}$ level rises, reaching maximum values in January-February. During winter months, the influence of intense fossil fuel combustion in the near-by town Zakopane and its surroundings can be visible in the recorded 5 concentrations of carbon dioxide. The peak-to-peak amplitude of the seasonal changes of the measured $\mathrm{CO}_{2}$ mixing ratios varies significantly from year to year, the average being around $20 \mathrm{ppm}$. The measured mixing ratios reveal an increasing trend, from average value around $360 \mathrm{ppm}$ in 1997 to around $380 \mathrm{ppm}$ in 2004. The $\mathrm{CO}_{2}$ levels recorded in Krakow are generally higher (around 440 ppm in 2004) with much higher 10 maxima of $\mathrm{CO}_{2}$ content, reaching more than $600 \mathrm{ppm}$.

The comparison of diurnal $\mathrm{CO}_{2}$ cycles recorded at Kasprowy Wierch and in Krakow is presented in Fig. 3. Figure 3a shows typical example of diurnal variability of $\mathrm{CO}_{2}$ mixing ratios, as recorded at both sites during summer time. Both the amplitude and the shape of diurnal $\mathrm{CO}_{2}$ changes differ considerably. In the urban environment, the 15 lowest $\mathrm{CO}_{2}$ mixing ratios are recorded generally during mid-day, when the convective activity of the lower atmosphere and resulting vertical mixing is at its maximum. In contrast, at the mountain site high $\mathrm{CO}_{2}$ mixing ratios are generally recorded during mid-day and early afternoon. This stems from sun-driven convection within the planetary bounday layer over Kasprowy Wierch "sucking" the $\mathrm{CO}_{2}$-laden air from the valleys towards the top of the mountain. Large differences in the amplitude of diurnal $\mathrm{CO}_{2}$ changes recorded at both sites are striking (Fig. 3b). In urban environment they may reach even ten times higher values that those recorded at the near-by mountain site. This is connected with presence of numerous local $\mathrm{CO}_{2}$ sources releasing relatively large amounts of $\mathrm{CO}_{2}$ into the urban atmosphere, which further leads to elevated concentrations and quasi-permanent excess of this gas above background concentrations, which cannot be completely removed by mixing processes. This is illustrated by Fig. 4 which shows daily mean values of $\mathrm{CO}_{2}$ mixing ratios recorded at both discussed sites during 2004. It is apparent from the data presented in Fig. 4 that the daily mean $\mathrm{CO}_{2}$ concentrations recorded at Krakow only seldom are comparable with those recorded

BGD

2, 1849-1865, 2005

\section{Carbon dioxide in southern Poland}

L. Chmura et al.

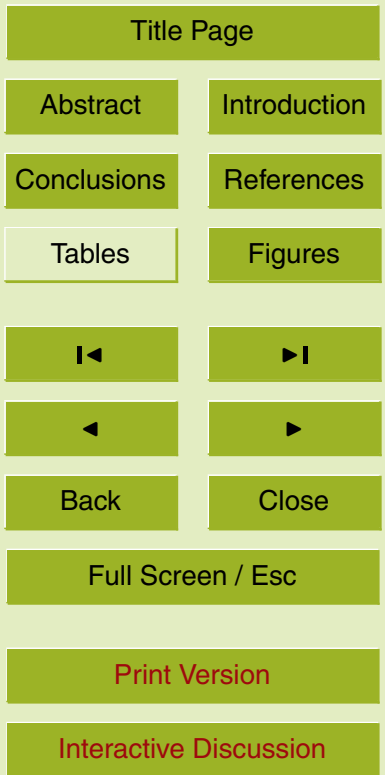

EGU 
at the same time at Kasprowy Wierch. At most cases they are significantly higher. The annual average $\mathrm{CO}_{2}$ concentration in 2004 recorded at Kasprowy Wierch was equal $378 \mathrm{ppm}$ while in Krakow it reached 408 ppm.

In addition to quasi-continuous observations of $\mathrm{CO}_{2}$ mixing ratios, also carbon iso5 tope composition of this gas was regularly measured at both monitoring sites. The measurements were performed on bi-weekly cumulative samples. This type of sampling is not adequate for studying short-term (diurnal) variability of the isotopic composition of atmospheric $\mathrm{CO}_{2}$.

Measurements of carbon isotope composition of atmospheric $\mathrm{CO}_{2}$ have been initi10 ated in Krakow in 1983. The early record of $\delta^{13} \mathrm{C}$ and $\Delta^{14} \mathrm{C}$ of atmospheric $\mathrm{CO}_{2}$ in Krakow was published by Kuc (1991) and later analysed by Kuc and Zimnoch (1998). A dedicated study focused daily variations of $\mathrm{CO}_{2}$ mixing ratio and its stable isotope composition $\left(\delta^{13} \mathrm{C}, \delta^{18} \mathrm{O}\right)$ within the urban atmosphere of Krakow was carried out by Zimnoch et al. (2004).

$15 \quad$ Figure 5 shows variations of ${ }^{14} \mathrm{C}$ and ${ }^{13} \mathrm{C}$ content in bi-weekly cumulative samples of atmospheric $\mathrm{CO}_{2}$ collected at Krakow and Kasprowy Wierch during the four-year period (2000-2003). The apparent offset of the $\delta^{13} \mathrm{C}$ record for Krakow with respect to Kasprowy Wierch data in the order of $1.2 \%$ (Fig. $5 \mathrm{~b}$ ), is attributed to local emissions of $\mathrm{CO}_{2}$ originating mostly from burning of fossil fuels. The offset of Krakow $\delta^{13} \mathrm{C}$ 20 record with respect to maritime reference station Mace Head is even higher (around $2 \%$ - GLOBALVIEW, 2004). Upper envelope of the two records presented in Fig. 5b reveals a small increasing trend towards less negative $\delta^{13} \mathrm{C}$ values, pointing to diminishing burden of regional atmosphere with $\mathrm{CO}_{2}$ of anthropogenic origin. The Kasprowy Wierch $\delta^{13} \mathrm{C}$ record approaches the values reported for "clean" reference sites (GLOB25 ALVIEW, 2004; Levin and Kromer, 1997). Seasonal fluctuations of $\delta^{13} \mathrm{C}$ visible at both discussed sites are shifted in phase. The Krakow record reveals lowest $\delta^{13} \mathrm{C}$ values during winter season, when local $\mathrm{CO}_{2}$ emissions due to burning of fossil fuels in the city (heating plus car traffic) are most intense. At Kasprowy Wierch, less negative $\delta^{13} \mathrm{C}$ values are generally recorded during winter time, when advection of biospheric $\mathrm{CO}_{2}$

BGD

2, 1849-1865, 2005

\section{Carbon dioxide in southern Poland}

L. Chmura et al.

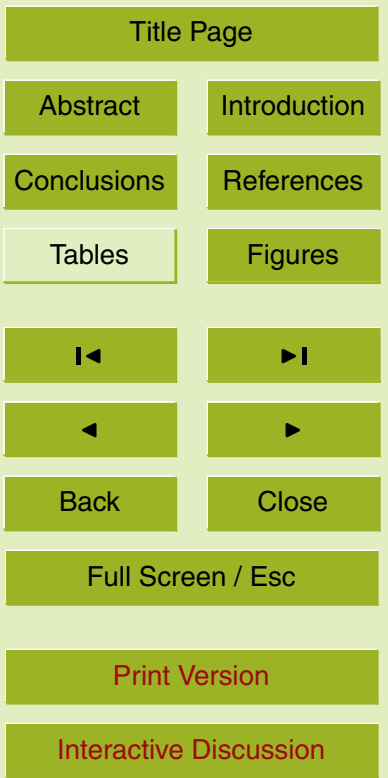

EGU 
from the valleys beneath the station is cut-off and free tropospheric air is "seen" by the station more frequently.

Substantial fluxes of $\mathrm{CO}_{2}$ of fossil-fuel origin lead to generally lower ${ }^{14} \mathrm{C}$ content in atmospheric $\mathrm{CO}_{2}$ recorded in urban environment, when compared to sites characterized 5 by smaller anthropopression. This effect is clearly seen in Fig. 5a which shows records of atmospheric ${ }^{14} \mathrm{CO}_{2}$ concentration available for Krakow and Kasprowy Wierch. The Krakow $\Delta^{14} \mathrm{C}$ record reveals distinct seasonality, with local minima of $\Delta^{14} \mathrm{C}$ occuring during winter months, when combustion of fossil fuels is most intense. This is not the case for Kasprowy Wierch where recorded fluctuations of $\Delta^{14} \mathrm{C}$ are much less pro10 nounced and irregular. However, a distinct decreasing trend of ${ }^{14} \mathrm{CO}_{2}$ concentration is visible at both discussed sites and the difference between mean $\Delta^{14} \mathrm{C}$ values recorded for Krakow and Kasprowy Wierch is smaller from year to year, pointing to diminishing fluxes of radiocarbon-free $\mathrm{CO}_{2}$ in Krakow. This is confirmed by energy-usage statistics for Krakow which indicate gradual reduction of coal burning in the municipal heating systems and reduction of low emission.

\section{Conclusions}

The presented work was focused on characterization of spatial and temporal variability of atmospheric concentrations of carbon dioxide and its isotopic composition, as recorded at two ground-level continental sites located in contrasting environments: (i) high-altitude mountaneous area, relatively free of anthropogenic influences, and (ii) typical urban environment with numerous local sources of carbon dioxide. Despite of relative proximity of those sites, substantial differences in both the recorded $\mathrm{CO}_{2}$ levels and their isotopic composition were detected. Human influence is clearly visible in the presented data, affecting both short- and long term changes of $\mathrm{CO}_{2}$ concentrations and its isotopic composition.

The $\mathrm{CO}_{2}$ mixing ratios measured in the urban atmosphere revealed quasi-permanent excess concentration of this gas when compared with near-by background atmosphere.

\section{Carbon dioxide in southern Poland}

L. Chmura et al.

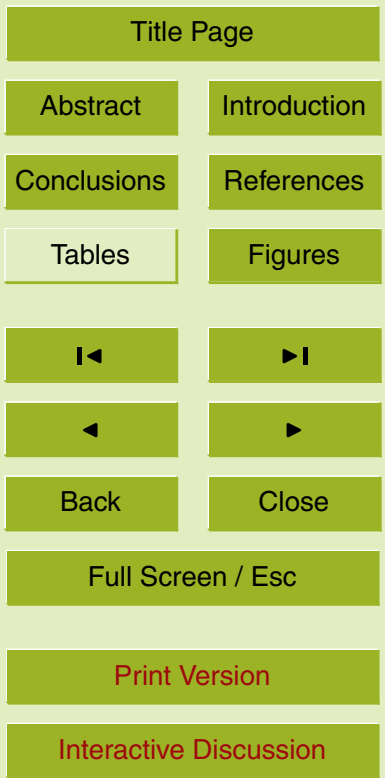

EGU 
The magnitude of this surplus is significant; in the studied case the annual mean $\mathrm{CO}_{2}$ concentration recorded in Krakow in 2004 was almost 10\% higher than that recorded at high-altitude mountain site (Kasprowy Wierch). Such effect is occuring probably in all urban centers. For large cities with several million inhabitants this permanent surpluss 5 of $\mathrm{CO}_{2}$ may be significantly higher than that observed in this study. The elevated concentrations of $\mathrm{CO}_{2}$ are expected near the ground where people live and the biosphere is present. Moreover, one may argue that local climate in urban centers will be further modified by the presence of these elevated $\mathrm{CO}_{2}$ concentrations enhancing the effect of urban heat islands.

10 Carbon isotopic composition of atmospheric $\mathrm{CO}_{2}$ proved to be an efficient tool for identification the surface $\mathrm{CO}_{2}$ fluxes into the atmosphere related to fossil fuel burning, their strength and temporal variability, as well as their influence on the recorded levels of this gas in the local atmosphere. The presented data clearly show that this influence can be monitored on long term basis. The available records of $\Delta^{14} \mathrm{C}$ for Krakow and Kasprowy Wierch suggest gradual reduction of ${ }^{14} \mathrm{C}$-free $\mathrm{CO}_{2}$ fluxes into the urban atmosphere of Krakow in the past several years.

Acknowledgements. Partial financial support of this work through statutory funds of the Polish Committee for Scientific Research (Project No. 11.11.220.01) as well as through EU Project CARBOEURO-IP (GOCE-CT-2003-505572) is kindly acknowledged. The authors wish to thank

B. Lewandowska for ${ }^{14} \mathrm{C}$ preparations, J. Fiedorowicz for sample collection and $\mathrm{H}$. Mroz for mass-spectrometric measurements.

\section{References}

Cias, P., Tans, P. P., Troiler, M., White, J. W. C., and Francey, R. J.: A large northern hemisphere terrestrial $\mathrm{CO}_{2}$ sink indicated by the ${ }^{13} \mathrm{C} /{ }^{12} \mathrm{C}$ ratio of atmospheric $\mathrm{CO}_{2}$, Science, 269, 1098$1102,1995$.

Coplen T. B.: New guidelines for reporting stable hydrogen, carbon and oxygen isotope-ratio data, Geochim. and Cosmochim. Acta., 60, 3359-3360, 1996.

BGD

2, 1849-1865, 2005

\section{Carbon dioxide in southern Poland}

L. Chmura et al.

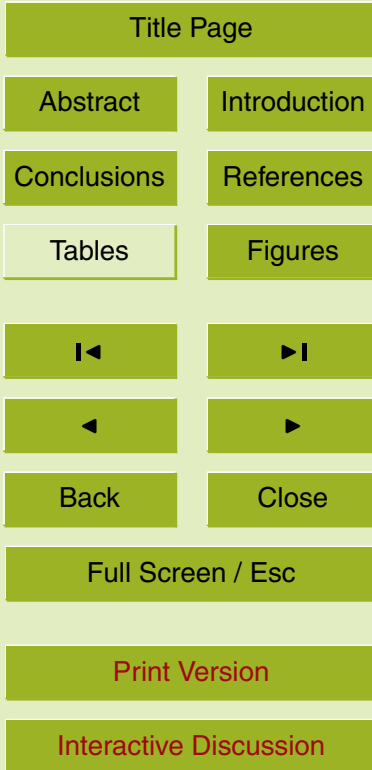

EGU 
Démeny, A. and Haszpra, L.: Stable isotope compositions of $\mathrm{CO}_{2}$ in background air and at polluted sites in Hungary, Rapid Comm. in Mass Spectr., 16, 797-804, 2002.

Florkowski, T., Grabczak, J., Kuc, T., and Rozanski, K.: Determination of radiocarbon in water by gas or liquid scintillation counting, Nukleonika, 20(11-12), 1053-1064, 1975.

5 GLOBALVIEW: Cooperative Atmospheric Data Integration Project - Carbon Dioxide, CMDLNOAA, Boulder, Colorado, (available via anonymous FTP at ftp://ftp.cmdl.noaa.gov, Path: ccg/co2/GLOBALVIEW), 2004.

IPCC: Integovernmental Panel on Climate Change, in: Climate Change 2001: The Scientific Basis, edited by: Houghton, J. T., The Third Report of Working Group 1, Cambridge Univer10 sity Press, Cambridge, 2001.

Keeling, C. D.: Global observations of atmospheric $\mathrm{CO}_{2}$, in: The Global Carbon Cycle, NATO ASI Series, vol. 15, edited by: Heimann, M., Springer-Verlag, New York, 1-30, 1993.

Keeling, C. D., Whorf, T. P., Wahlen, M., and Van der Plicht, H.: Interannual extremes in the rate of rise of atmospheric carbon dioxide since 1980, Nature, 375, 666-670, 1995.

Kuc, T.: Concentration and carbon isotopic composition of atmospheric $\mathrm{CO}_{2}$ in southern Poland, Tellus, 43B, 373-378, 1991.

Kuc, T. and Zimnoch, M.: Changes of the $\mathrm{CO}_{2}$ sources and sinks in a polluted urban area (southern Poland) over the last decade derived from the carbon isotope composition, Radiocarbon, 40, 417-423, 1998.

20 Kuc, T., Rozanski, K., Zimnoch, M., Necki, J. M., and Korus, A.: Anthropogenic emissions of $\mathrm{CO}_{2}$ and $\mathrm{CH}_{4}$ in an urban environment, Applied Energy, 75(3-4), 193-203, 2003.

Levin, I. and Kromer, B.: Twenty years of high precision atmospheric ${ }^{14} \mathrm{CO}_{2}$ observations at Schauinsland station, Germany, Radiocarbon, 39(2), 205-218, 1997.

Levin, I. and Hesshaimer, V.: Radiocarbon - a unique tracer of global carbon cycle dynamics, Radiocarbon, 42, 69-80, 2002.

Marland, G., Boden, T. A., and Andres, R. J.: Global, regional and national $\mathrm{CO}_{2}$ emission estimates from fossil fuel burning, cement production, and gas flaring: 1751-1999, vol. 2002, Carbon Dioxide Information Analysis Center, Oak Ridge, Ten., 2002.

Necki, J., Schmidt, M., Rozanski, K., Zimnoch, M., Korus, A., Lasa, J., Graul, R., and Levin, I.:

30 Six-year record of atmospheric carbon dioxide and methane at a high-altitude mountain site in Poland, Tellus, 55B, 94-104, 2003.

Stuiver, M. and Polach, H. A.: Discussion: Reporting of ${ }^{14} \mathrm{C}$ data, Radiocarbon, vol. 19, no. 3, 355-363, 1977.

\section{Carbon dioxide in southern Poland}

L. Chmura et al.

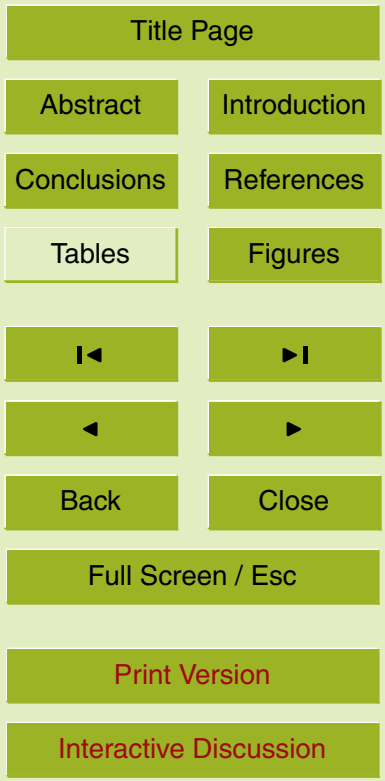

EGU 
Thoning, K. W., Tans, P. P., and Komhyr, W. D.: Atmospheric carbon dioxide at Mauna Loa Observatory 2. Analysis of the NOAA GMCC data, 1974-1985, J. Geophys. Res., 94, 85498565, 1989.

Zimnoch, M., Florkowski, T., Necki, J. M., and Neubert, R. E. M.: Diurnal variability of $\delta^{13} \mathrm{C}$ and $\delta^{18} \mathrm{O}$ of atmospheric $\mathrm{CO}_{2}$ in the urban atmosphere of Krakow, Poland, Isotopes in Environmental and Health Studies, 40(2), 129-143, 2004.

\section{BGD}

2, 1849-1865, 2005

\section{Carbon dioxide in southern Poland}

L. Chmura et al.

Title Page

Abstract Introduction

Conclusions

References

Tables

Figures

14

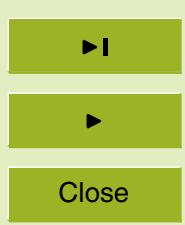

Back

Full Screen / Esc

Print Version

Interactive Discussion 


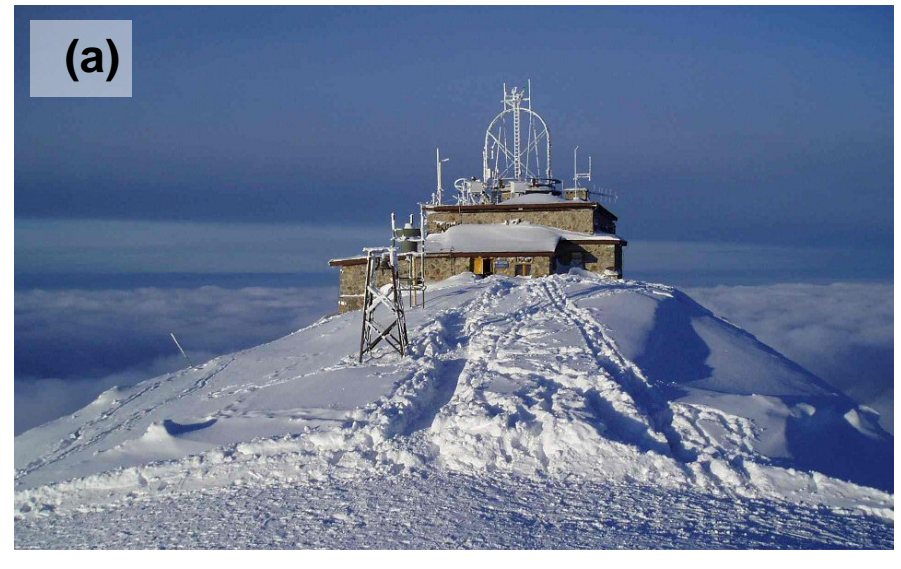

\section{BGD}

2, 1849-1865, 2005

\section{Carbon dioxide in southern Poland}

L. Chmura et al.
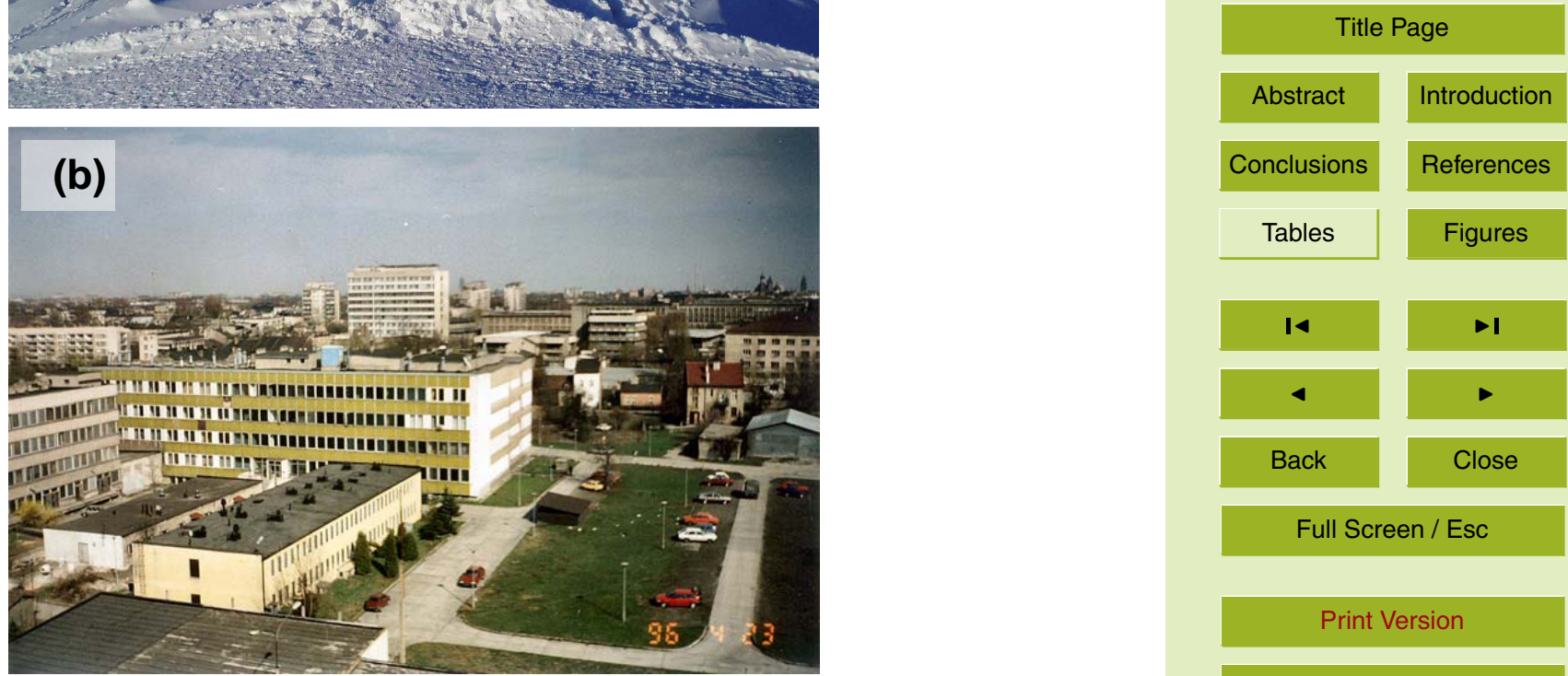

Full Screen / Esc

Print Version

Interactive Discussion

EGU

Fig. 1. Aerial view of the $\mathrm{CO}_{2}$ monitoring sites discussed in the paper: (a) high-altitude mountain site Kasprowy Wierch, Tatra Mountains; (b) city of Krakow. 


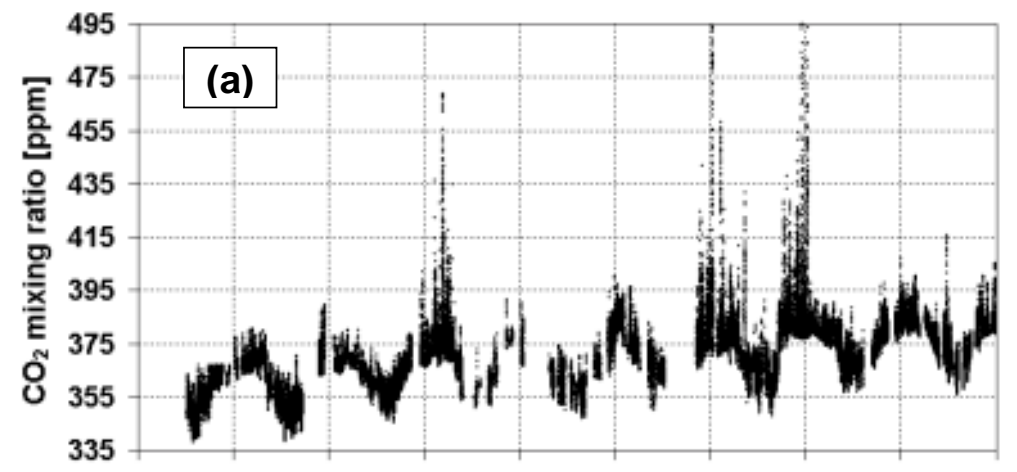

\section{BGD}

2, 1849-1865, 2005

\section{Carbon dioxide in southern Poland}

L. Chmura et al.

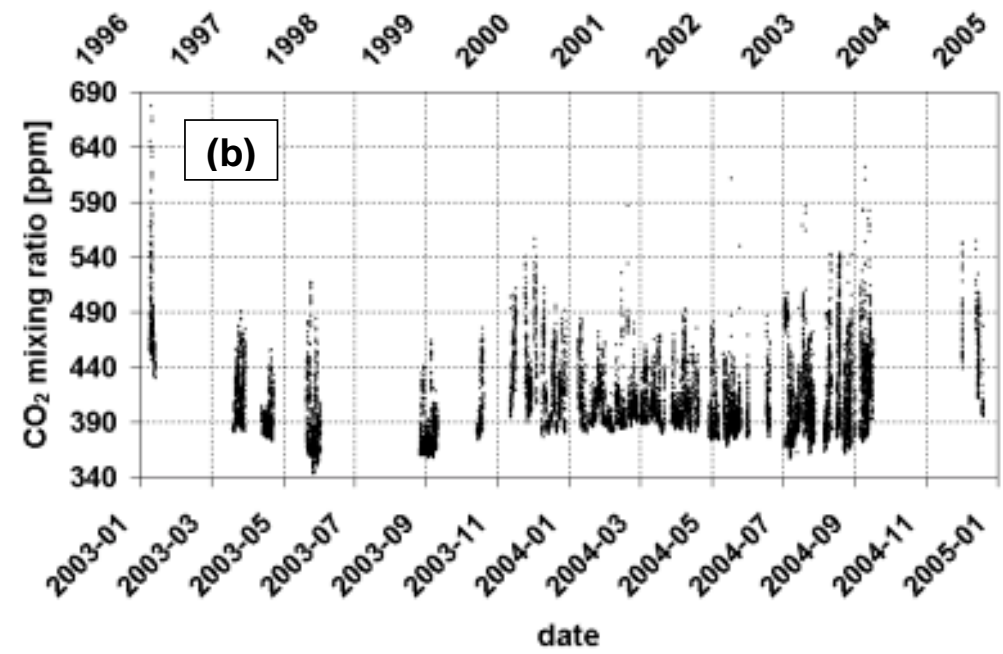

Title Page

Abstract

Introduction

Conclusions

References

Tables

Figures

14

$>1$

4

Back

Close

\section{Full Screen / Esc}

Print Version

Interactive Discussion

EGU 


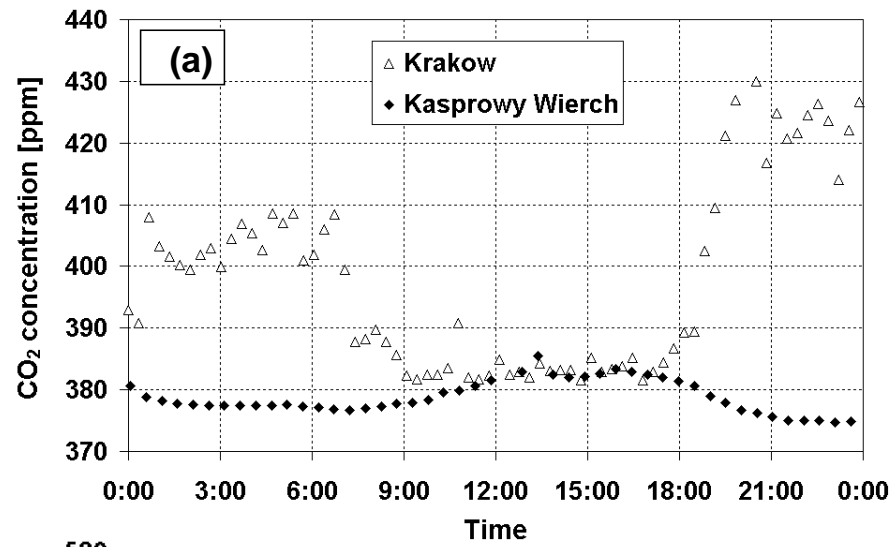

$2,1849-1865,2005$

\section{Carbon dioxide in southern Poland}

L. Chmura et al.

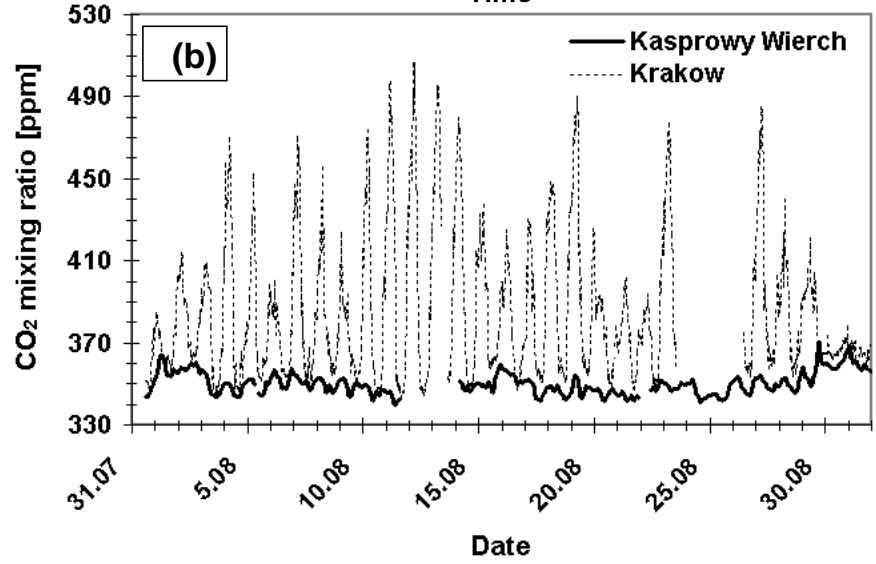

Title Page

Abstract

Introduction

Conclusions

References

Tables

Figures

14

$>1$

4

Back

Close

Full Screen / Esc

Print Version

Fig. 3. Short-term variability of $\mathrm{CO}_{2}$ mixing ratios as observed at Kasprowy Wierch and Krakow stations. (a) typical example of diurnal changes of $\mathrm{CO}_{2}$ mixing ratio occurring at both monitoring sites, (b) comparison of the magnitude of diurnal changes of $\mathrm{CO}_{2}$ mixing ratio recorded at Kasprowy Wierch and Krakow stations during summer (August 2002). 


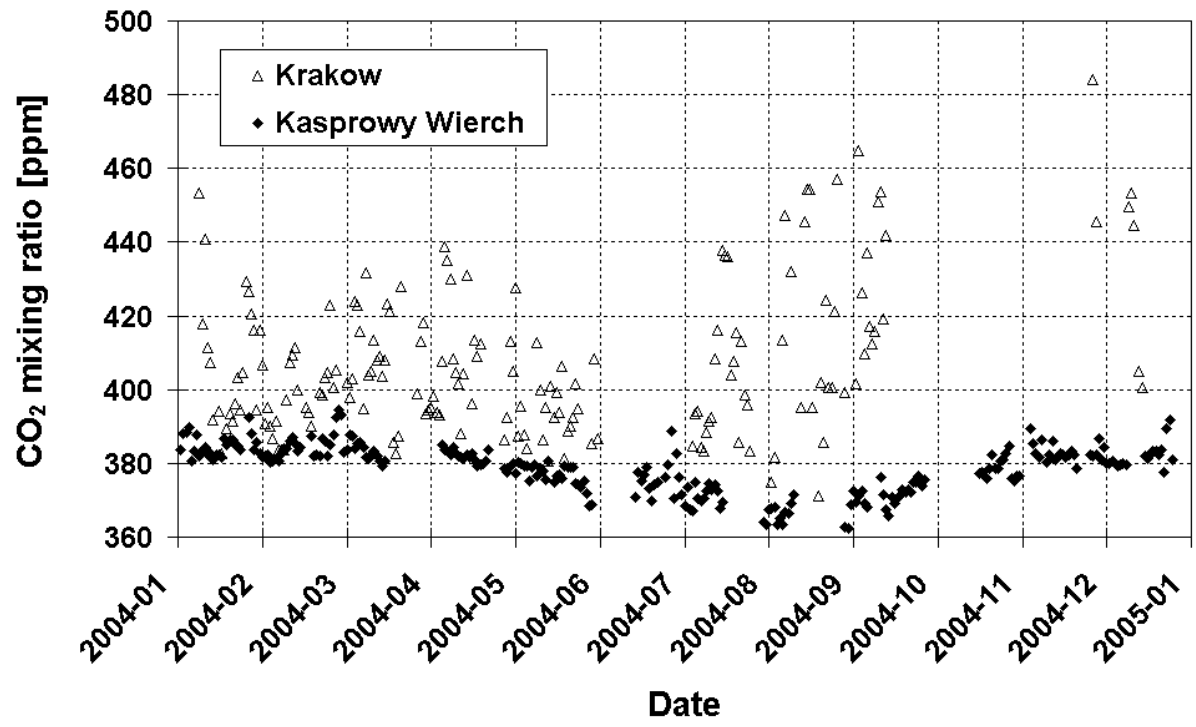

Fig. 4. Daily mean values of atmospheric $\mathrm{CO}_{2}$ mixing ratio recorded during 2004 at Kasprowy Wierch and Krakow stations.

\section{Carbon dioxide in southern Poland}

L. Chmura et al.

\section{Title Page}

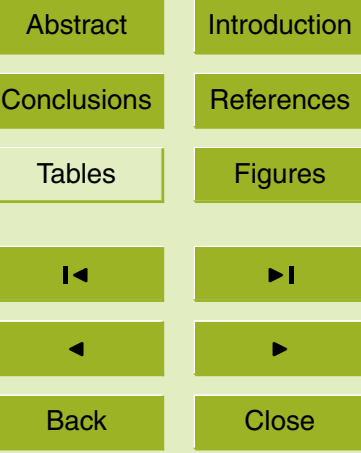

Full Screen / Esc

Print Version

Interactive Discussion 


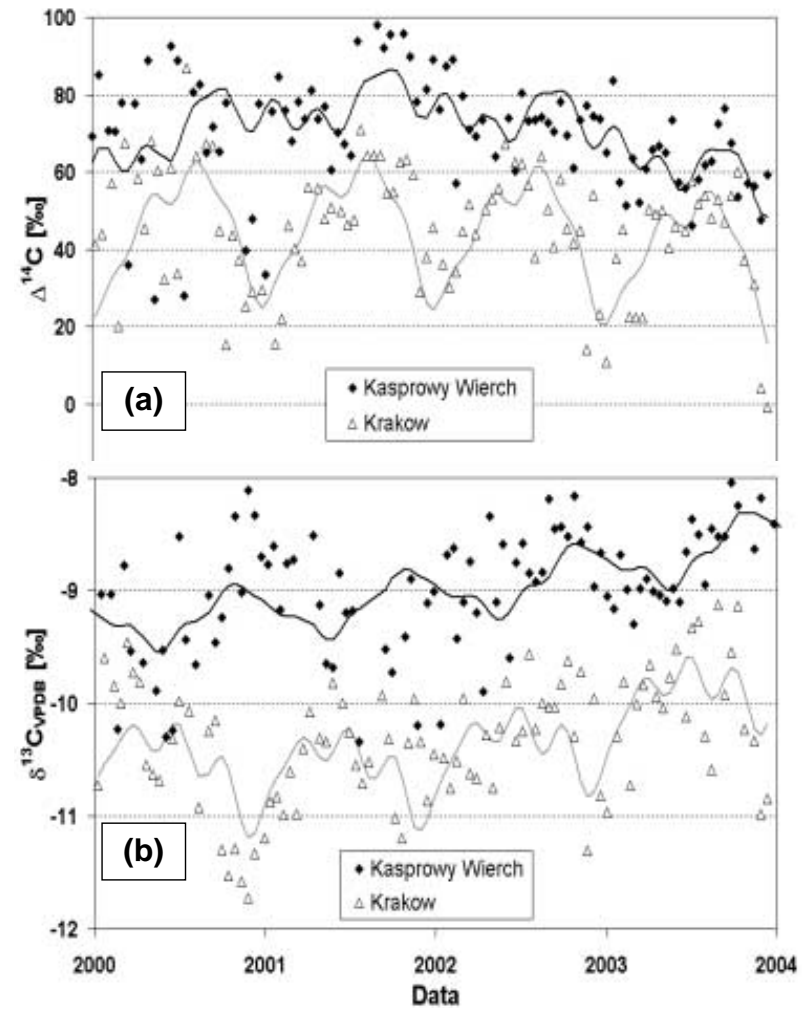

BGD

2, 1849-1865, 2005

\section{Carbon dioxide in southern Poland}

L. Chmura et al.

\section{Title Page}

Abstract

Introduction

Conclusions

References

Tables

Figures

14

\section{-1}

4

Back

Close

Full Screen / Esc

Print Version

Interactive Discussion 